\title{
First record of the land operculate snail Cyclophorus pfeifferi Reeve, 1861 (Mollusca, Cyclophoroidea, Cyclophoridae) from India
}

\author{
Sheikh Sajan ${ }^{1}$, Deepti', Sonam Jahan ${ }^{1}$, Arghya Chakrabarty ${ }^{1}$, \\ Sandeep Kushwaha ${ }^{1}$, Lalit Kumar Sharma ${ }^{1}$, Basudev Tripathy ${ }^{1}$, Kailash Chandra ${ }^{1}$ \\ 1 Zoological Survey of India, Prani Vigyan Bhawan, M Block, New Alipore, Kolkata, West Bengal, \\ 700053, India
}

Corresponding authors: Sheikh Sajan (sksajan.sajan@gmail.com), Lalit Kumar Sharma (lalitganga@gmail.com)

Received 15 November 2019 | Accepted 5 March 2020 | Published 30 June 2020

Citation: Sajan S, Deepti, Jahan S, Chakrabarty A, Kushwaha S, Sharma LK, Tripathy B, Chandra K (2020) First record of the land operculate snail Cyclophorus pfeifferi Reeve, 1861 (Mollusca, Cyclophoroidea, Cyclophoridae) from India. Travaux du Muséum National d'Histoire Naturelle “Grigore Antipa” 63(1): 51-61. https://doi. $\operatorname{org} / 10.3897 / \operatorname{travaux} .63 . e 48523$

\begin{abstract}
Through the present manuscript, we are reporting for the first time the presence of Cyclophorus pfeifferi Reeve, 1861 in India. Previously, this species of land snail was reported only from South-East Asian countries Malaysia, Thailand, Cambodia and Vietnam. The specimens were collected during field surveys in Dampa Tiger Reserve in Mizoram state, India. The presence of C. pfeifferi in India reveals the range expansion and long-distance dispersal abilities of the species. Here we discuss the taxonomy, ecology and possible routes of dispersal of the species in India.
\end{abstract}

\section{Keywords}

Caenogastropoda, dispersal, distribution, north-east, range expansion, South Asia

\section{Introduction}

The land operculate snail genus Cyclophorus Montfort, 1810 belongs to the family Cyclophoridae, subclass Caenogastropoda. This genus is one of the largest and diverse groups within the family Cyclophoridae, the fossil record of which dates back to the early Tertiary period (first period of the Cenozoic Era) (Gordon and 
Olson 1995; Egorov and Greke 2007). Globally, there are 180 nominal species reported throughout the sub-tropical and tropical habitats of South and South-East Asia, as well as the southern areas of China, Korea, and Japan (Reeve 1861; Kobelt and Möllendorff 1897; Kobelt 1902, 1908; Gude 1921; Laidlaw 1928; Zilch 1956; Raheem et al. 2014; Nantarat et al. 2014a, 2014b; Tripathy et al. 2018; Do and Do 2019; Sajan et al. 2019a). In India, 46 nominal species of Cyclophorus have been described during the colonial period. Most species are restricted in distribution and endemic to different regions in India (Ramakrishna et al. 2010; Tripathy et al. 2018; Sajan et al. 2019a). However, in recent years, the populations of Cyclophorus snails appear to have noticeably decreased due to habitat fragmentation, land-use changes and unsustainable harvesting because of their high demand as food resource (Sen et al. 2012; Nantarat et al. 2014b; Tripathy et al. 2018).

The operculate land snail Cyclophorus pfeifferi Reeve, 1861 has been previously reported from the tropical rainforests of Penang in Malaysia (Reeve 1861; Laidlaw 1928); Koh Si Chang, Tale Sap, Songkhla and Tak in Thailand (Laidlaw 1928; Nantarat et al. 2014a, b); as well as Muong La and Tuan Giao Districts in Vietnam (Do and Do 2019). However, through the present note we report for the first time the presence of the species in India. Furthermore, we also attempted to discuss the ecology and possible dispersal routes of the species.

\section{Material and Methods}

The Dampa Tiger Reserve (DTR) covers an area of $500 \mathrm{~km}^{2}$ and is located in the Mamit District of Mizoram, India. The topography of the reserve is largely represented by hilly terrain, where the elevation ranges between $250-1100 \mathrm{~m}$. The lowland area vegetation of the reserve is represented by tropical evergreen forest communities, while the highland undulations are dominated by semi-evergreen forests. The annual precipitation of the region ranges from 2000 to $2500 \mathrm{~mm}$, and the average diurnal temperature ranges $12^{\circ} \mathrm{C}-35^{\circ} \mathrm{C}$ (Devi et al. 2011).

The specimens were collected during the recent field surveys at Damparengpui area in DTR during 2018-19. The active visual search method was used for collection on different macro habitat viz. leaf litter, under stone, woods, decaying logs, and soil following a standard sampling protocol (Emberton et al. 1996, Sajan et al. 2017). Shells of Cyclophorus were collected along with other species of molluscs in the families Ariophantidae, Helicarionidae and Pupinidae. The collected dry specimens were washed thoroughly in tap water and preserved directly in container and live specimens of other groups were preserved in 70\% ethanol. Specimens were photographed in the laboratory using a Nikon D7000 DSLR camera with an AF-S Micro Nikkor $105 \mathrm{~mm}$ VR lens and shell measurements were taken on Mitutoyo dial calliper. Whereas, the distributional map was generated by using QGIS, A Coruña (ver. 3.10.1). The specimens were identified as C. pfeifferi based on published illustrations and literature (Reeve 1861; Kobelt 1902; Nantarat et al. 2014b; Do and Do 2019). 
The identified specimens were deposited in the National Zoological Collection of Zoological Survey of India (NZSI).

Abbreviations and acronyms

$\mathrm{AH}$ - aperture height

asl - above sea level

AW - aperture width

DTR - Dampa Tiger Reserve

leg. - legit (i.e. the collector)

NZSI - National Zoological Collection of the Zoological Survey of India

SD - shell diameter

SH - shell height

spm. - specimen

spms. - specimens

\section{Results}

Systematics:

Family Cyclophoridae Gray, 1847

Subfamily Cyclophorinae Gray, 1847

Genus Cyclophorus Montfort, 1810

Type species. Helix volvulus Müller, 1774 [Accepted as Cyclophorus volvulus (Müller, 1774)]

Cyclophorus pfeifferi Reeve, 1861

(Figure 1A-E)

Examined material. India: 1 spm.; Mizoram, Mamit District, DTR, Damparengpui; $23.69461^{\circ} \mathrm{N}, 092.40825^{\circ} \mathrm{E} ; 671 \mathrm{~m}$ asl; 09 December 2018; leg. Sandeep Kushwaha; within the leaf litter; NZSI M.32735/9 : 2 spms.; Mizoram,

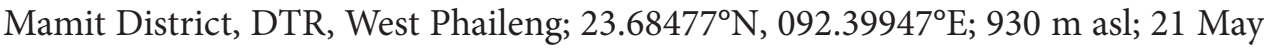
2019; leg. Sonam Jahan; from forest floor; NZSI M.33528/9 : 12 spms.; Mizoram, Mamit District, DTR, $23.700505^{\circ} \mathrm{N}, 092.432161^{\circ} \mathrm{E} ; 382 \mathrm{~m}$ asl; 24 May 2019; leg. Deepti; from forest floor; NZSI M.33527/9.

Diagnosis. The species of the genus Cyclophorus are mainly differentiated based on shell size, shape and sculpture on the shell surface. The shape of the peristome and umbilicus are considered important diagnosis characters for species identification (Kobelt and Möllendorff 1897; Kobelt 1902, 1908; Gude 1921; Laidlaw 1928). The identification of the Cyclophorus pfeifferi is based on the wide and rounded aperture, thickened peristome, distinctly reflected and folded back (Reeve 1861; Do and Do 2019). 
Description. Shell large, thick, conically turbinated with elevated spire, chocolate brown in colour with a dark brown band below the periphery; apex pointed, suture impressed and convex; shell rather obsoletely keel at periphery that continues up to the peristome, body whorl rounded and stout; 51/4 whorls, rounded, that regularly increase; aperture large, rounded, slightly oblique, and expanded; peristome orange in colour, thickened and distinctly reflected and folded back; umbilicus deep and partially covered by the outer peristome.

Measurements. SD 44.40-55.10 mm, SH 35.20-42.00 mm, AH 25.90-33.30 $\mathrm{mm}$, AW 26.70-34.10 mm (n=9).

\section{Discussion}

This is the first record of $C$. pfeifferi from India, expanding thus the geographical range of the species from South-East Asia to South Asia (Table 1). The collected specimens of $C$. pfeifferi were identified and confirmed based on morphological diagnosis (Reeve 1861; Do and Do 2019) and distinguished from closely related species C. tuba (Sowerby, 1842), and C. speciosus (Philippi, 1847) based on size, last whorl and peristome characters (Figs $1 \mathrm{~F}-\mathrm{G}$ ). Recent phylogenetic studies confirmed that C. pfeifferi is closely related to C. affinis Theobald, 1858, although C. affinis is easily distinguished based on its smaller size and simple peristome (Nantarat et al. 2014b).

Cyclophorus species prefer a moist environment with relatively lower temperature, and they are predominately active through the rainy season during the day time, crawling on the forest floor, tree trunks and leaves (Vermeulen 1999). Cyclophorus pfeifferi has been reported from tropical rainforests in Indo-Burma biodiversity hot-

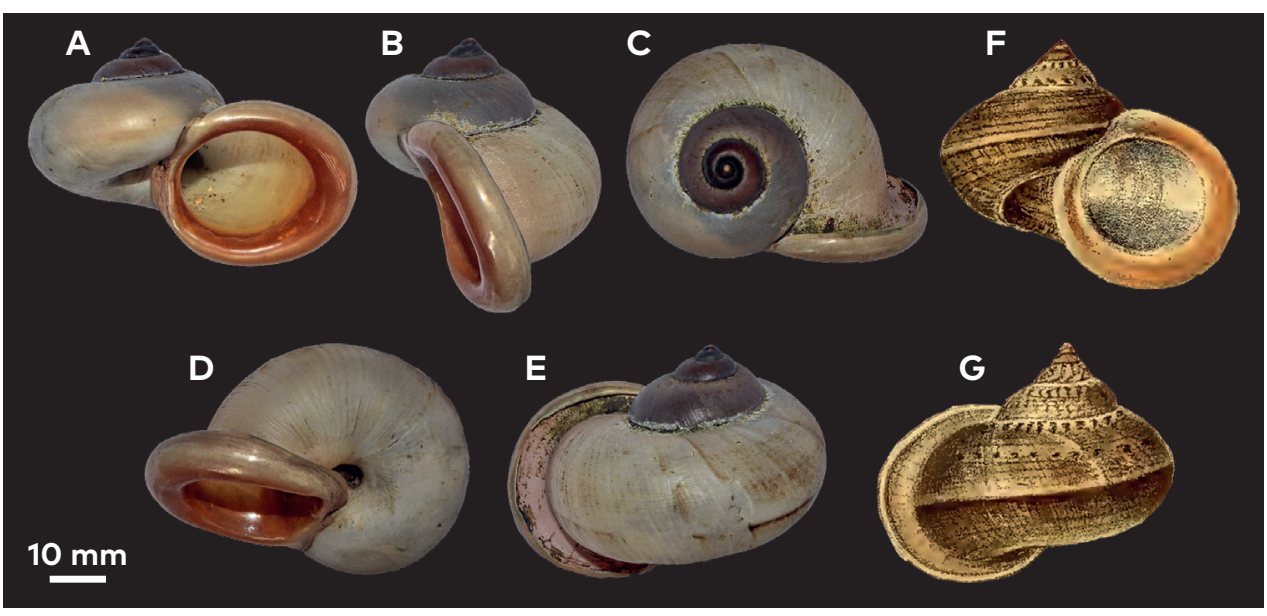

Figure 1. Cyclophorus pfeifferi. A-E. Apertural, apical, umbilical and abapertural view, NZSI M.32735/9. F-G. Apertural and abapertural view (illustration adopted from literature after Reeve, 1861). 
spot, from the moist environments in Malaysia, Thailand, and Vietnam, in between the altitudinal range of 100-800 m asl (Reeve 1861; Nantarat et al. 2014a, b; Do and Do 2019), with a single record below the minimum range (Laidlaw 1928). The tropical rainforests characterized by Pan et al. (2013), with annual mean temperature of $\sim 20-25^{\circ} \mathrm{C}$, annual precipitation $>1500 \mathrm{~mm}$ and canopy height of $25-50 \mathrm{~m}$ seem to be the suitable habitat for C. pfeifferi. The new record from DTR occupies a similar forest and habitat with previous records (Figs 2 and 3). The shells of $C$. pfeifferi were collected from the floor and under the moist leaf litter of the tropical evergreen forest that presents similar climatic features. This may indicate that $C$. pfeifferi prefers these kinds of ecological features.

Geographically, the north-eastern region of India is part of the Indo-Burma Biodiversity Hotspot and the Mizoram-Manipur-Kachin rainforest ecoregion (Myers et al. 2000; Olson et al. 2001). The latter has a rich biodiversity and acts as a transitional zone for edge species viz. Cyclophorus affinis Theobald, 1858, C. theobaldianus Benson, 1857, C. aurantiacus (Schumacher, 1786), C. speciosus (Philippi, 1847), C. perdix roepstorffiana Godwin-Austen, 1895, C. expansus (Pfeiffer, 1851), C. spironema (Pfeiffer, 1854), C. pyrotrema Benson, 1854, C. pearsoni (Benson, 1851), C. bensoni (Pfeiffer, 1852), and C. zebrinus (Benson, 1836). However, species Cyclophorus affinis, C. aurantiacus, C. theobaldianus, C. zebrinus, C. bensoni, C. expansus and C. speciosus have long-distance dispersal abilities within

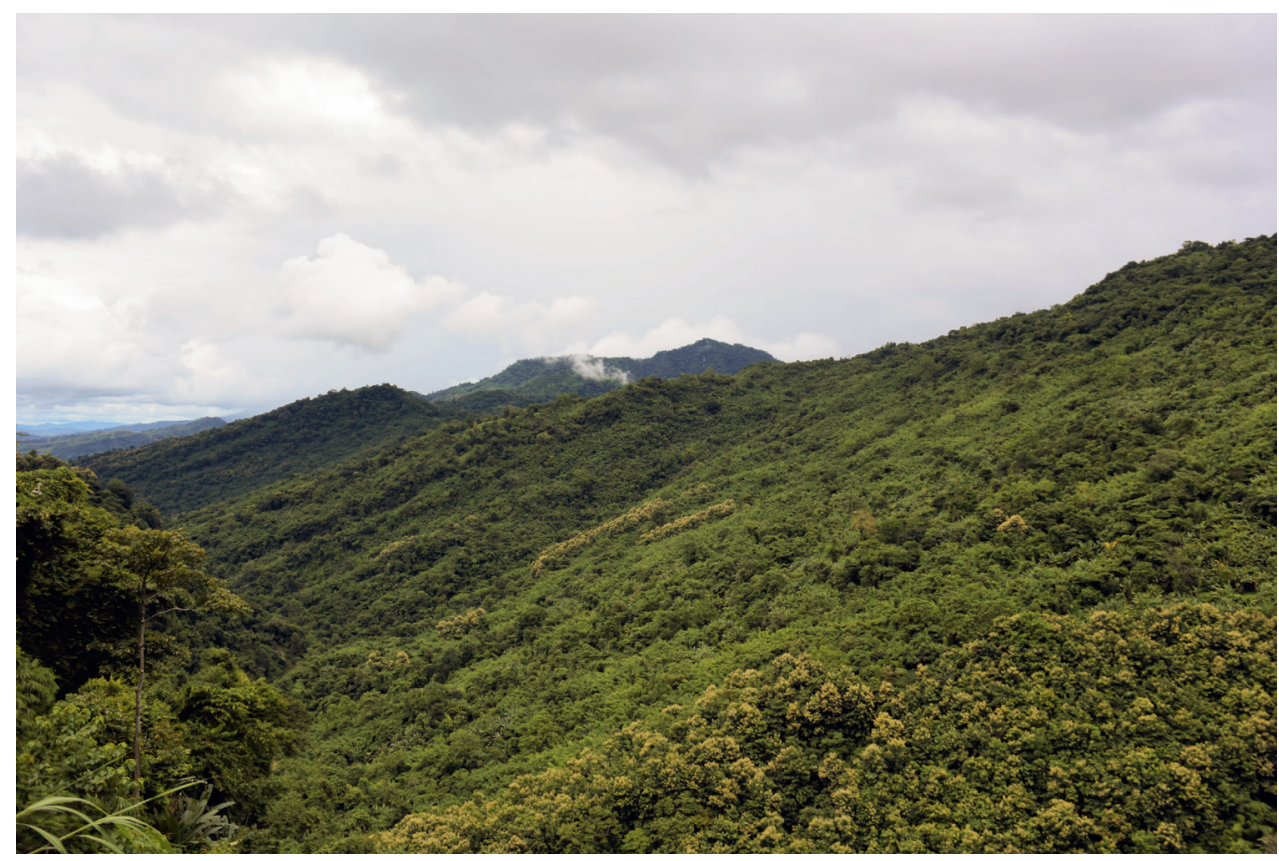

Figure 2. Forests and habitat of Cyclophorus pfeifferi in Dampa Tiger Reserve, Mizoram, India (Photograph by LKS). 


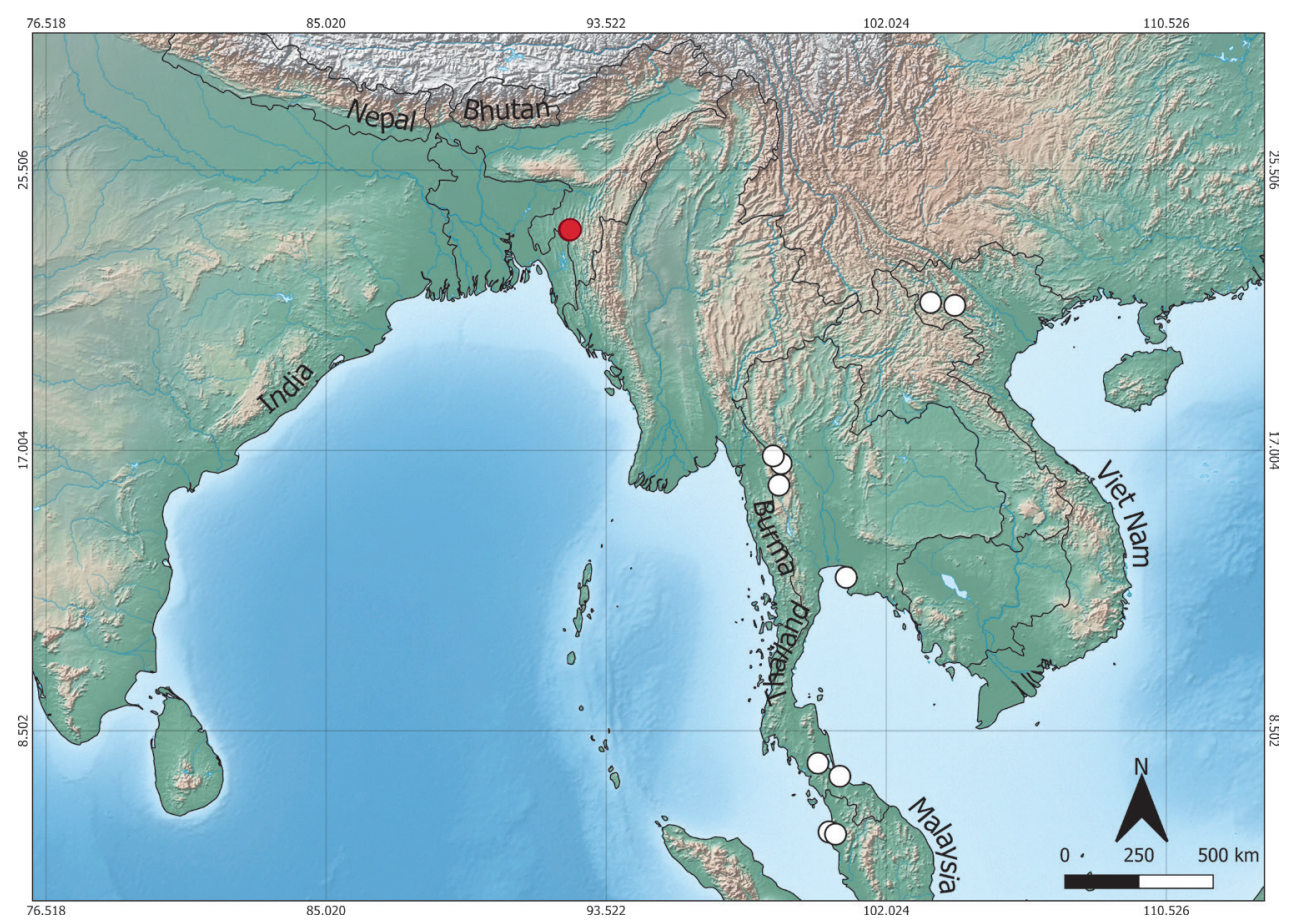

Figure 3. Distribution pattern of Cyclophorus pfeifferi in South and South-east Asia, where white dots shows the previous record and the new record from India is represented by the red dot (see distributional table).

tropical rainforests from South to South-East Asia (Gude 1921; Ramakrishna et al. 2010; Nantarat et al. 2014b; Tripathy et al. 2018; Do and Do 2019). Moreover, continuous mountain ranges and forest connectivity may act as highways for movement and dispersal (Aubry et al. 2006; Rayfield et al. 2016). The recent record of the Burmese land snails Oxytesta shanensis (Godwin-Austen, 1883) from Namdapha Tiger Reserve, Arunachal Pradesh, and the current record may help towards understanding the long-distance dispersal ability of terrestrial gastropods, and connectivity patterns between the existing eco-regions in the Indo-Burma hotspot (Myers et al. 2000; Olson et al. 2001; Sajan et al. 2019b). However, attention towards and conservation of lesser known invertebrate species are apparently very low as compared to the actions towards vertebrate fauna. Also, the land-use changes, habitat fragmentation, urbanisation, and habitat shrinkage are the major causes for serious decline of the molluscan populations. In our landscape survey, the increase in shifting cultivation (Jhum) use, collection of firewood, recurring forest fire and collection of non-timber forest products (NTFPs) from the area were observed. Such activities may threaten the habitats and the species composition. Therefore, further systematic field surveys need to be carried out for better understanding of species composition and coexistence of Malayan fauna. 


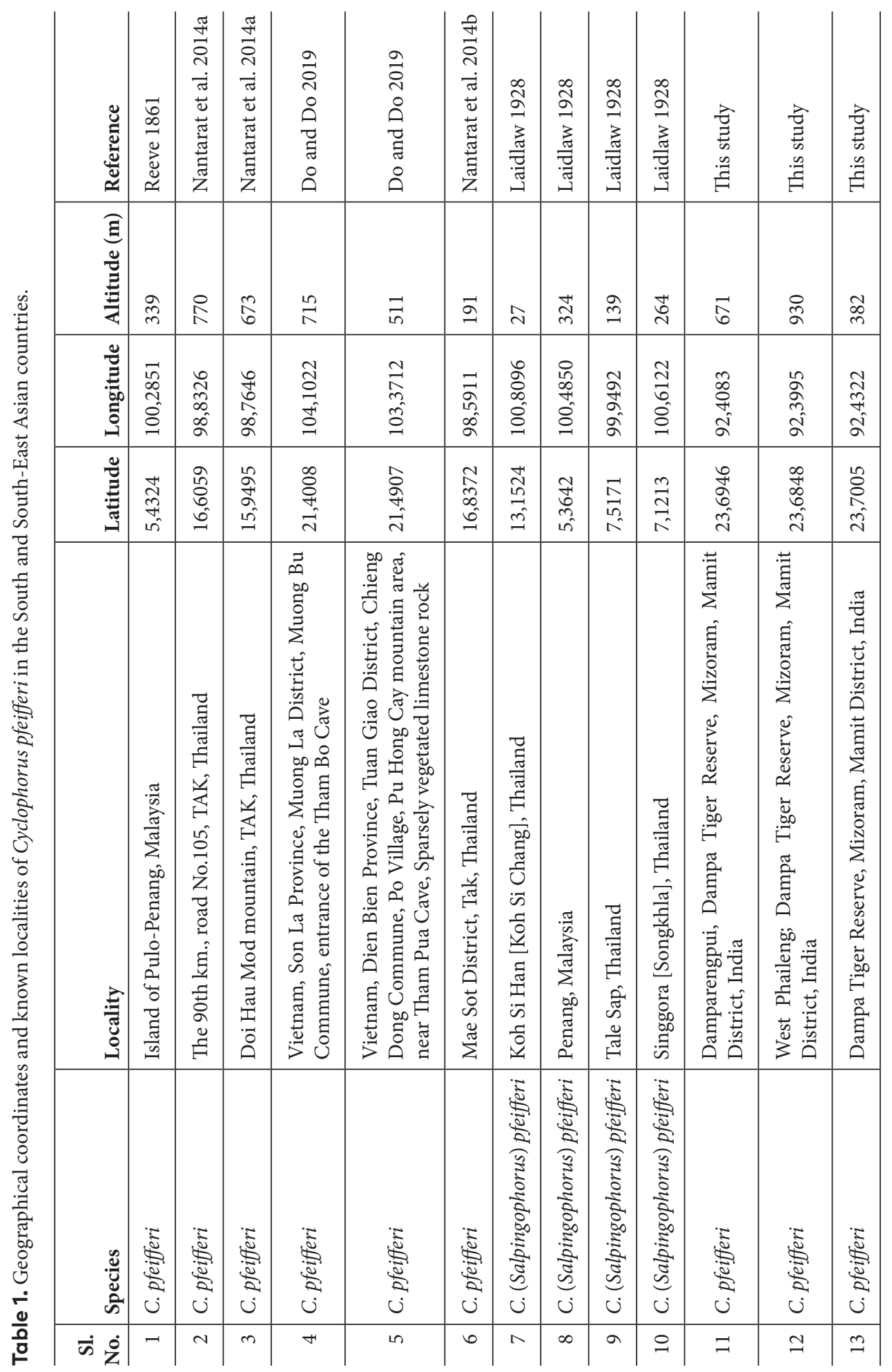




\section{Acknowledgements}

The authors are grateful to the Director of Zoological Survey of India, Kolkata for providing the necessary facilities for the study. The support of Field Director and Forests Staff of Dampa Tiger Reserve for issuing the research permit and for accommodation is greatly appreciated. This study was funded by MoEF \& CC through NMHS scheme with project ID: NMHS/2017-18/MG44/28. Furthermore, author SS also thankful to funding agency NMHS Grant (NMHS-LG-2016/0011/8509-8) for fellowship support. We are grateful to the editor and two anonymous referees for review comments.

\section{References}

Aubry S, Labaune C, Magnin F, Roche P, Kiss L (2006) Active and passive dispersal of an invading land snail in Mediterranean France. Journal of Animal Ecology 75: 802-813. https://doi.org/10.1111/j.1365-2656.2006.01100.x

Devi HS, Hmingthangpuii, Sharma KK (2011) Change in vegetation cover of Dampa tiger reserve, Mizoram, North East India: a serious threat to tiger population. Journal of Experimental Sciences 2(9): 1-6.

Do DS, Nhuong Do V (2019) Family Cyclophoridae in Vietnam (Gastropoda: Cyclophoroidea): the genus Cyclophorus Montfort, 1810. Ruthenica 29(1): 1-53.

Egorov R, Greke K (2007) The Genus Cyclophorus Montfort, 1810: Systematics and Nomenclature. Club Conchylia Informationen 38(3/4): 57-64.

Emberton KC, Pearce TA, Randanala R (1996) Quantitatively sampling land-snail diversities in Madagascan rainforests. Malacologia 38: 203-212.

Gordon MS, Olson EC (1995) The transitions of organisms from aquatic to terrestrial life. Columbia University Press, New York, 312 pp.

Godwin-Austen HH (1882-1920) Land and freshwater Mollusca of India, including South Arabia, Baluchistan, Afghanistan, Kashmir, Nepal, Burmah, Pegu, Tenasserim, Malay Peninsula, Ceylon, and other islands of the Indian Ocean. Supplementary to Messrs. Theobald and Hanley's Conchologica Indica. London: Taylor and Francis, 1-65.

Gray JE (1847) A list of the genera of recent Mollusca, their synonyma and types. Proceedings of the Zoological Society of London 15: 129-219. https://www.biodiversitylibrary. org/page/12862913

Gude GK (1921) Mollusca III (Land Operculates). In: Shipley A, Marshall A (Eds) The Fauna of British India including Ceylon and Burma. Taylor and Francis, London, 1-386.

Kobelt W (1902) Cyclophoridae. In: Kobelt W (Ed.) Das Tierreich Eine Zusammenstellung und Kennzeichnung der Rezenten Tierformen 16 [The animal kingdom A compilation and labeling of the recent animal forms 16]. Berlin, R. Friedländer und Sohn, 1-662. [in German]

Kobelt W (1907-1908) Die gedeckelten Lungenschnecken (Cyclostomacea) [The capped lung slugs (Cyclostomacea)]: In: Abbildungennach der Naturmit Beschreibungen. 
Dritte Abteilung. Cyclophoridae I. Systematisches Conchylien-Cabinet von Martini und Chemnitz 1(19): 401-711. [in German]

Kobelt W, Möllendorff OF (1897) Catalog der gegenwärtigleben dbekannten Pneumonopomen [Catalog of currently known pneumonopomes]. Nachrichtsblatt der Deutschen Malakozoologischen Gesellschaft 1(3): 73-192. [in German]

Laidlaw FF (1928) A list of the land and fresh-water Mollusca of the Malay Peninsula with notes. Journal of the Malayan Branch of the Royal Asiatic Society 6(1): 25-37.

Montfort P [Denys de] (1810) Conchyliologie systématique et classification méthodique des coquilles [Systematic Conchology and Methodical Classification of Shells]. Paris, Schoell. Vol. 2: pp. $676+$ 16. http://www.biodiversitylibrary.org/bibliography/10571 [in French]

Müller OF (1774) Vermium terrestrium et fluviatilium, seu animalium infusorium, Helminthicorum, et testaceorum, non marinorum, succincta historia. Vol 2: I-XXXVI, 1-214, 10 unnumbered pages. Havniae et Lipsiae, apud Heineck et Faber, ex officina Molleriana. https://www.biodiversitylibrary.org/page/12893715

Myers N, Mittermeier RA, Mittermeier CG, da Fonseca GAB, Kent J (2000) Biodiversity hotspots for conservation priorities. Nature 403: 853-858. https://doi.org/10.1038/35002501

Nantarat N, Sutcharit C, Tongkerd P, Ablett J, Naggs F, Panha S (2014a) An annotated catalogue of type specimens of the land snail genus Cyclophorus Monfort, 1810 (Caenogastropoda, Cyclophoridae) in the Natural History Museum, London. ZooKeys 411: 1-56. https://doi.org/10.3897/zookeys.411.7258

Nantarat N, Tongkerd P, Sutcharit C, Wade CM, Naggs F, Panha S (2014b) Phylogenetic relationships of the land operculate land snail genus Cyclophorus Monfort, 1810 in Thailand. Molecular Phylogenetics and Evolution 70: 99-111. https://doi.org/10.1016/j. ympev.2013.09.013

Olson DM, Dinerstein E, Wikramanayake ED, Burgess ND, Powell GVN, Underwood EC, D’Amico JA, Itoua I, Strand HE, Morrison JC, Loucks CJ, Allnutt TF, Ricketts TH, Kura Y, Lamoreux JF, Wettengel WW, Hedao P, Kassem KR (2001) Terrestrial ecoregions of the World: A new map of life on Earth: A new global map of terrestrial ecoregions provides an innovative tool for conserving biodiversity. BioScience 51(11): 933-938. https://doi.org/10.1641/0006-3568(2001)051[0933:TEOTWA]2.0.CO;2

Pan Y, Birdsey RA, Phillips OL, Jackson RB (2013) The structure, distribution, and biomass of the world's forests. Annual Review of Ecology, Evolution, and Systematics 44: 593-622. https://doi.org/10.1146/annurev-ecolsys-110512-135914

Raheem DC, Taylor H, Ablett J, Preece RC, Aravind NA, Naggs F (2014) A Systematic Revision of the Land Snails of the Western Ghats of India. Tropical Natural History Supplement 4(1-13): 1-285.

Ramakrishna, Mitra SC, Dey A (2010) Annotated checklist of Indian land molluscs. Record of the Zoological Survey of India, Occasional Paper No. 306: 1-359.

Rayfield B, Pelletier D, Dumitru M, Cardille JA, Gonzalez A (2016) Multipurpose habitat networks for short-range and long-range connectivity: a new method combining graph and circuit connectivity. Methods in Ecology and Evolution 7: 222-231. https://doi. org/10.1111/2041-210X.12470 
Reeve LA 1861 (1862) Conchologia Iconica: or, Illustrations of the shells of Molluscous animals. 13, Monograph of the Genus Cyclophorus, pls 1-20. Lovell Reeve \& Co., London, 570 pp.

Sajan SK, Tripathy B, Sivakumar K (2017) Sampling protocol for terrestrial molluscs in the high altitude landscape of the Indian Himalayas. Scientific Transactions in Environment and Technovation 11(1): 54-57.

Sajan S, Tripathy B, Naggs, F (2019a) Clarification of the status of the type series and of the holotype of Cyclophorus (Glossostylus) koboensis Godwin-Austen, 1915 (Mollusca, Caenogastropoda, Cyclophoridae) in Nantarat et al. (2014). Zookeys 882: 25-28. https:// doi.org/10.3897/zookeys.882.38423

Sajan SK, Tripathy B, Chandra K (2019b) New record of a land snail Oxytesta shanensis (Godwin-Austen, 1883) (Helicarionoidea: Ariophantidae) from India. Journal of Bombay Natural History Society 116: 29-31. https://doi.org/10.17087/jbnhs/2019/ v116/122331

Sen S, Ravikanth G, Aravind NA (2012) Land snails (Mollusca: Gastropoda) of India: status, threats and conservation strategies. Journal of Threatened Taxa 4(11): 3029-3037. https://doi.org/10.11609/JoTT.o2722.3029-37

Tripathy B, Sajan SK, Mukhopadhyay A (2018) Mollusca. In: Chandra K, Gupta D, Gopi KC, Tripathy B, Kumar V (Eds) Faunal diversity of Indian Himalaya. Published by the Director, Zoological Survey of India. Kolkata, 785-796.

Vermeulen JJ (1999) Notes on the non-marine molluscs of the island of Borneo 9. The genera Cyclophorus, Leptopoma, and Craspedotropis (Gastropoda Prosobranchia: Cyclophoridae). Basteria 63: 139-163.

Zilch A (1956) Die Typen und Typoide des Natur-Museums Senckenberg, 17: Mollusca, Cyclophoridae, Cyclophorinae-Cyclophoreae (3) [The types and typoids of the Senckenberg Nature Museum, 17: Mollusca, Cyclophoridae, Cyclophorinae-Cyclophoreae (3)]. Archiv für Molluskenkunde 85: 33-54. [in German] 
Appendix 1. Detailed morphometric measurements of the shells C. pfeifferi collected from DTR $(n=9)$, where, other specimens has been partially damaged and not included in the measurements.

\begin{tabular}{|c|c|c|c|c|c|c|}
\hline $\begin{array}{r}\text { Sl. } \\
\text { No. }\end{array}$ & Species & Locality & SD & SH & AH & AW \\
\hline 1 & C. pfeifferi & $\begin{array}{l}\text { Damparengpui, Dampa Tiger Reserve, } \\
\text { Mizoram, Mamit District, India } \\
\left(23.69461^{\circ} \mathrm{N}, 92.40825^{\circ} \mathrm{E} \text {, Alt. } 671 \mathrm{~m} .\right)\end{array}$ & 55.1 & 42 & 33.3 & 34.1 \\
\hline 2 & C. pfeifferi & $\begin{array}{l}\text { West Phaileng; Dampa Tiger Reserve, } \\
\text { Mizoram, Mamit District, India } \\
\left(23.68477^{\circ} \mathrm{N}, 92.39947^{\circ} \mathrm{E} \text {, Alt. } 930 \mathrm{~m} .\right)\end{array}$ & 44.4 & 35.7 & 26.8 & 27.1 \\
\hline 3 & C. pfeifferi & $\begin{array}{l}\text { West Phaileng; Dampa Tiger Reserve, } \\
\text { Mizoram, Mamit District, India } \\
\left(23.68477^{\circ} \mathrm{N}, 92.39947^{\circ} \mathrm{E} \text {, Alt. } 930 \mathrm{~m} .\right)\end{array}$ & 50.3 & 38.9 & 30.6 & 30.9 \\
\hline 4 & C. pfeifferi & $\begin{array}{l}\text { Dampa Tiger Reserve, } \\
\text { Mizoram, Mamit District, India } \\
\left(23.700505^{\circ} \mathrm{N}, 92.432161^{\circ} \mathrm{E}, \text { Alt. } 382 \mathrm{~m} .\right)\end{array}$ & 45.7 & 35.4 & 25.9 & 26.7 \\
\hline 5 & C. pfeifferi & $\begin{array}{l}\text { Dampa Tiger Reserve, } \\
\text { Mizoram, Mamit District, India } \\
\left(23.700505^{\circ} \mathrm{N}, 92.432161^{\circ} \mathrm{E} \text {, Alt. } 382 \mathrm{~m} .\right)\end{array}$ & 54.7 & 40.6 & 31.7 & 33.1 \\
\hline 6 & C. pfeifferi & $\begin{array}{l}\text { Dampa Tiger Reserve, } \\
\text { Mizoram, Mamit District, India } \\
\left(23.700505^{\circ} \mathrm{N}, 92.432161^{\circ} \mathrm{E}, \text { Alt. } 382 \mathrm{~m} .\right)\end{array}$ & 48.5 & 39.2 & 28.9 & 28.7 \\
\hline 7 & C. pfeifferi & $\begin{array}{l}\text { Dampa Tiger Reserve, } \\
\text { Mizoram, Mamit District, India } \\
\left(23.700505^{\circ} \mathrm{N}, 92.432161^{\circ} \mathrm{E}, \text { Alt. } 382 \mathrm{~m} .\right)\end{array}$ & 47.9 & 36 & 27.8 & 29.3 \\
\hline 8 & C. pfeifferi & $\begin{array}{l}\text { Dampa Tiger Reserve, } \\
\text { Mizoram, Mamit District, India } \\
\left(23.700505^{\circ} \mathrm{N}, 92.432161^{\circ} \mathrm{E}, \text { Alt. } 382 \mathrm{~m} .\right)\end{array}$ & 46 & 35.2 & 27.5 & 27.7 \\
\hline 9 & C. pfeifferi & $\begin{array}{l}\text { Dampa Tiger Reserve, } \\
\text { Mizoram, Mamit District, India } \\
\left(23.700505^{\circ} \mathrm{N}, 92.432161^{\circ} \mathrm{E}, \text { Alt. } 382 \mathrm{~m} .\right)\end{array}$ & 44.4 & 34.2 & 27 & 27.5 \\
\hline
\end{tabular}

